\title{
TINJAUAN KELENGKAPAN FORMULIR RESUME MEDIS DENGAN REGULASI SNARS (STANDAR NASIONAL AKREDITASI RUMAH SAKIT) DI RSUD dr. SOEDONO MADIUN
}

\author{
Reza Geta Pratiwi \\ rezageta@gmail.com \\ Prodi D-III Rekam Medis dan Informasi Kesehatan STIKES Buana Husada Ponorogo
}

\begin{abstract}
Medical Records are written evidence that can be justified, one of which is a medical resume. The aim is to make it easier for the hospital if there are lawsuits in court. The purpose of this study is to find out the completeness of the medical resume form in accordance with SNARS regulations (National Hospital Accreditation Standards) in dr. Soedono Madiun. This type of research is quantitative research using descriptive methods and cross sectional approaches. Data collection techniques in this study using interview and observation techniques with a checklist.The results of research at dr. Soedono Madiun, namely the completeness of medical resume forms in accordance with SNARS regulations of $60 \%$ of 57 medical record files and incomplete by $40 \%$ of 38 medical record files. The suggestion from this research is that the hospital in controlling incompleteness is to socialize the SPO (Standard Operating Procedure) regarding the completeness of filling in medical record documents and make a list of incompleteness then recapitulate the number of incompleteness and by conducting concurrent analysis which is carried out while the patient is still being treated or during treatment. which is done in the treatment room.
\end{abstract}

Keywords: Completeness, medical resume and SNARS

\section{PENDAHULUAN}

Kesehatan adalah kebutuhan yang harus dipenuhi bagi setiap individu. Fasilitas pelayanan kesehatan yang memberikan pelayanan kuratif dan rehabilitatif kepada pasien salah satunya adalah rumah sakit. Menurut Permenkes No. 4 Tahun 2018 tentang Kewajiban Rumah Sakit dan Kewajiban Pasien bahwa fasilitas pelayanan kesehatan dalam mencapai mutu sebaiknya memberikan pelayanan yang baik kepada pasien, tersedianya data yang lengkap dan akurat untuk meningkatkan kualitas pelayanan kesehatan. Pelayanan kesehatan yang diberikan kepada pasien sebaiknya yang bermutu demi meningkatkan derajat kesehatan masyarakat yang setinggi-tingginya.

Salah satu isi dari rekam medis adalah resume medis. Resume medis adalah ringkasan pulang pasien yang telah diberikan oleh tenaga kesehatan terkait dari awal perawatan dan pengobatan hingga pasien pulang (Hatta, 2013). Isi resume medis yang harus ada dalam regulasi SNARS (Standar Nasional Akreditasi Rumah Sakit) adalah diagnosis, tindakan, obat yang diberikan, kondisi pasien, tanda tangan pasien/keluarga.

Pengisian rekam medis yang lengkap dan jelas akan menghasilkan sebuah informasi yang dapat diterima oleh pasien karena dalam rekam medis berisi riwayat penyakit, diagnosa, tindakan, obat yang diberikan kepada pasien. Kelengkapan dokumen rekam medis juga akan mempermudah tenaga rekam medis dalam penyelenggaraannya dan dapat digunakan sebagai informasi bagi rumah sakit untuk bahan evaluasi dan perencanaan pelayanan kesehatan yang akan datang.

Berdasarkan observasi awal yang dilakukan peneliti pada tanggal 16 Januari 2019 bahwa di RSUD dr. 


\section{Jurnal Delima Harapan $\mathbf{2 0 2 0}$}

Soedono Madiun masih sering terjadi ketidaklengkapan pengisian berkas rekam medis salah satunya resume medis. Masalah yang sering tidak lengkap dalam pengisian resume medis adalah indikasi pasien dirawat, tanda tangan keluarga atau pasien, diagnosa masuk, diagnosa keluar dan nama dokter. Berdasarkan observasi, dari 35 berkas rekam medis bagian resume medis tersebut ada 14 formulir resume medis yang lengkap dan untuk 21 formulir resume medis yang belum lengkap. Presentase untuk kelengkapan resume medis tersebut adalah $40 \%$ dan untuk ketidaklengkapan resume medis adalah $60 \%$.

Penyebab kurang lengkapnya pengisian resume medis tersebut karena setelah pelayanan kepada pasien selesai, dokter ada yang tidak melengkapi rekam medis karena dengan anggapan untuk mempercepat pelayanan dan terbatasnya waktu yang ada karena banyaknya pasien, kondisi dokter tertentu seperti ada kepentingan ke luar kota atuapun saat dokter cuti. Dampak yang ditimbulkan dari tidak lengkapnya pengisian dokumen rekam medis yaitu isi dari rekam medis yang terkait dengan hasil pemeriksaan pasien tidak dapat dipertanggungjawabkan isinya jika terjadi suatu masalah yang akan berlanjut di jalur hukum, rumah sakit tidak dapat mempertahankan akreditasi SNARS yang sudah dicapinya karena kurangnya mutu pelayanan kepada pasien dan jika diagnosa tidak lengkap maka akan berdampak kepada pasien karena pasien tidak mengetahui apa diagnosa yang diberikan oleh dokter.

Solusi dari adanya ketidaklengkapan pengisian dokumen rekam medis yaitu dengan membuat kebijakan, panduan, SOP tentang prosedur pengisian berkas rekam medis dan jika sudah ada SOP, lebih dijalankan lagi prosedurnya secara maksimal karena rekam medis sangat penting isinya bagi pasien dan bagi rumah sakit dimana setiap dokter atau dokter gigi yang merawat atau melayani pasien tersebut wajib membuat rekam medis dan menulis dengan lengkap dan harus segera dibuat setelah pelayanan kepada pasien selesai.

\section{METODE PENELITIAN}

Metode penelitian yang digunakan dalam penelitian ini adalah metode deskriptif dan pendekatan cross sectional. Lokasi penelitian adalah di RSUD dr. Soedono Madiun. Sampel penelitian adalah 95 berkas rekam medis pasien dan 1 petugas assembling. Hasil pengolahan data dianalisa secara dekriptif.

\section{HASIL PENELITIAN}

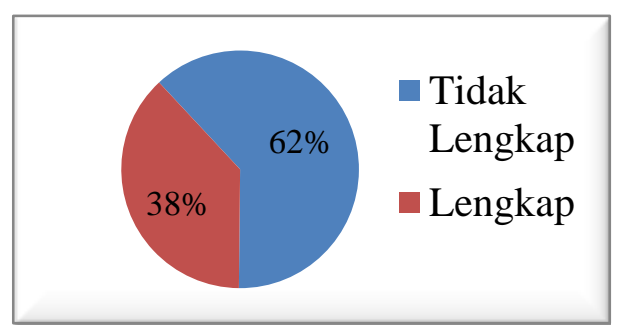

Gambar 1. Indikasi Pasien Masuk Dirawat, Diagnosis dan Komorbiditas Lain

Dari hasil perhitungan, presentase kelengkapan formulir resume medis pasien rawat inap pada indikasi pasien masuk dirawat, diagnosis dan komorbiditas lain sebesar 38\% dari 36 berkas rekam medis, sedangkan untuk yang tidak lengkap sebesar $62 \%$ dari 59 berkas rekam medis.

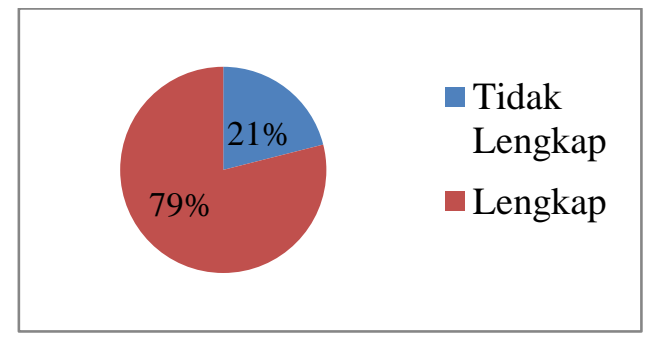

Gambar 2. Temuan Fisik Penting dan Temuan-temuan Lain

Dari hasil perhitungan, presentase kelengkapan formulir resume medis pasien rawat inap pada temuan fisik penting dan temuan-temuan lain sebesar $79 \%$ dari 75 berkas rekam medis, sedangkan untuk yang tidak lengkap 
sebesar $21 \%$ dari 20 berkas rekam medis.

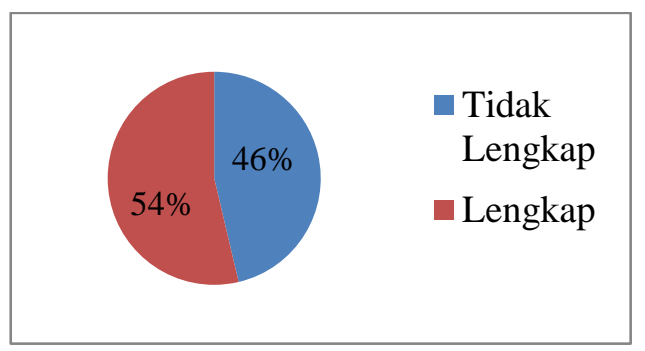

Gambar 3. Tindakan Diagnostik dan Prosedur Terapi yang Telah Dikerjakan

Dari hasil perhitungan, presentase kelengkapan formulir resume medis pasien rawat inap pada tindakan diagnostik dan prosedur terapi yang telah dikerjakan sebesar $54 \%$ dari 51 berkas rekam medis, sedangkan untuk yang tidak lengkap sebesar $46 \%$ dari 44 berkas rekam medis.

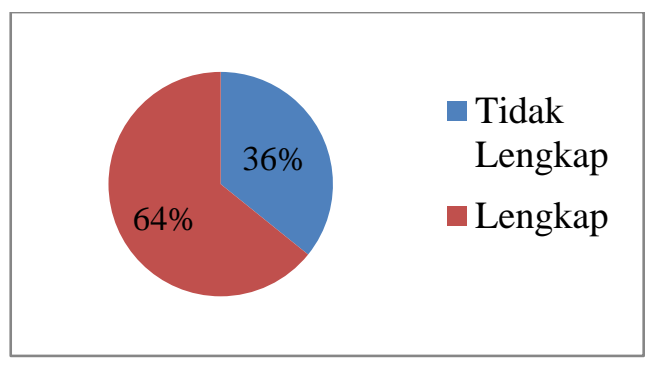

Gambar 4. Obat yang Diberikan selama Dirawat Inap

Dari hasil perhitungan, presentase kelengkapan formulir resume medis pasien rawat inap pada obat yang diberikan selama dirawat inap dengan potensi akibat efek residual setelah obat tidak diteruskan dan semua obat yang harus digunakan di rumah sebesar $64 \%$ dari 61 berkas rekam medis, sedangkan untuk yang tidak lengkap sebesar 36\% dari 34 berkas rekam medis.

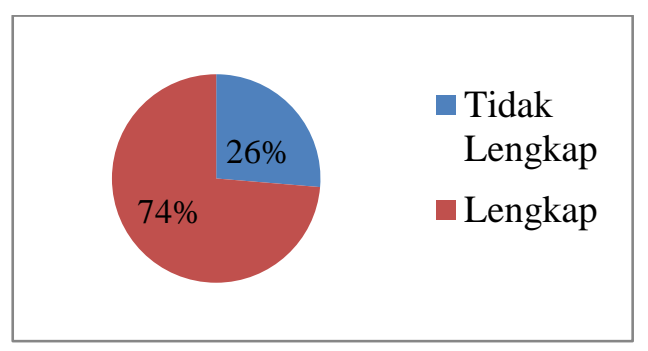

Gambar 5. Kondisi Pasien (Status Present)
Dari hasil perhitungan, presentase kelengkapan formulir resume medis pasien rawat inap pada kondisi pasien (status present) sebesar $74 \%$ dari 70 berkas rekam medis, sedangkan untuk yang tidak lengkap sebesar $26 \%$ dari 25 berkas rekam medis.

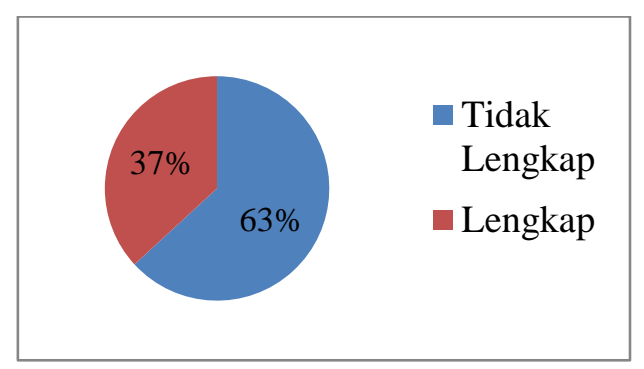

Gambar 6. Ringkasan Memuat Instruksi Tindak Lanjut

Dari hasil perhitungan, presentase kelengkapan formulir resume medis pasien rawat inap pada ringkasan memuat instruksi tindak lanjut sebesar $37 \%$ dari 35 berkas rekam medis, sedangkan untuk yang tidak lengkap sebesar $63 \%$ dari 60 berkas rekam medis.

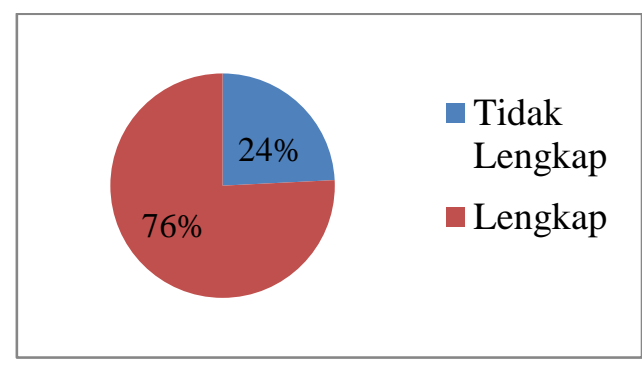

Gambar 7. Ringkasan Pasien Pulang Dijelaskan dan Ditandatangani oleh Pasien/Keluarga

Dari hasil perhitungan, presentase kelengkapan formulir resume medis pasien rawat inap pada ringkasan pasien pulang dijelaskan dan ditandatangani oleh pasien/keluarga sebesar $76 \%$ dari 72 berkas rekam medis, sedangkan untuk yang tidak lengkap sebesar $24 \%$ dari 23 berkas rekam medis. 


\section{Jurnal Delima Harapan $\mathbf{2 0 2 0}$}

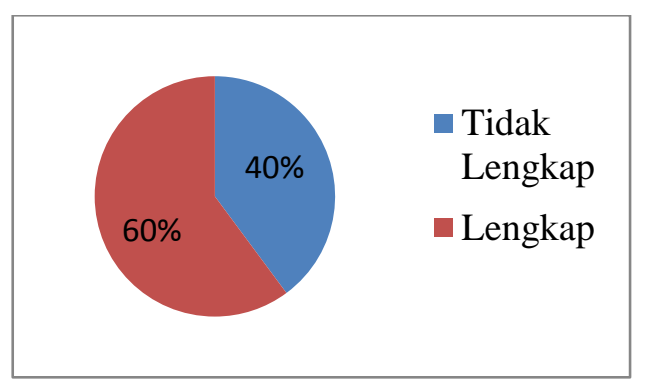

Gambar 8. Kelengkapan Formulir Resume Medis Pasien Rawat Inap Bulan Mei di RSUD dr. Soedono

Dari hasil perhitungan, presentase kelengkapan pengisian resume medis sesuai dengan SNARS sebesar 60\% dari 57 berkas rekam medis dan tidak lengkap sebesar $40 \%$ dari 38 berkas rekam medis. Berdasarkan buku SNARS, untuk skor yang diperoleh adalah skor 5 (terpenuhi sebagian) karena rentang capaian sesuai standar adalah 20-79 sedangkan yang diperoleh sebesar $60 \%$ sehingga mendapatkan skor 5 .

\section{PEMBAHASAN}

\section{Indikasi Pasien Masuk Dirawat, Diagnosis dan Komorbiditas Lain}

Berdasarkan hasil penelitian, untuk kelengkapan indikasi pasien masuk dirawat, diagnosis dan komorbiditas lain sebesar $38 \%$ dan tidak lengkap sebesar $62 \%$. Bagian dari indikasi pasien masuk dirawat, diagnosis dan komorbiditas lain terdiri dari alasan/indikasi dirawat, diagnosa masuk, diagnosa keluar, komplikasi/diagnosa penyerta. Pengisian pada bagian ini banyak yang tidak lengkap dikarenakan dokter lupa tidak mengisi alasan dirawat, diagnosa utama, diagnosa keluar atau komplikasi jika tidak ada sebaiknya menggunakan tanda - jadi tidak kosong sehingga tidak membuat bagian rekam medis bingung apakah ini tidak ada atau dokter lupa mengisi (Sudra, 2013). Faktor lain karena adanya miss komunikasi antara dokter dan perawat. Sedangkan untuk pengisian yang lengkap dikarenakan berkaitan dengan diagnosa pasien yang merupakan faktor penentu pelayanan kesehatan kepada pasien dan berkaitan juga dengan klaim BPJS jika diagnosa tidak lengkap, maka klaim BPJS tidak di ACC. Diagnosa jika tidak lengkap maka riwayat pasien tidak berkesinambungan yang dapat merugikan pasien ataupun rumah sakit.

Menurut Permenkes Nomor 269/MenKes/Per/III/2008, tentang Rekam Medis menyatakan bahwa rekam medis pasien salah satunya formulir resume medis pasien yang memuat identitas pasien, diagnosa masuk dan indikasi pasien dirawat, ringkasan hasil pemeriksaan fisik dan penunjang, diagnosis akhir, pengobatan dan tindak lanjut, nama dan tanda tangan dokter atau dokter gigi yang memberikan pelayanan kesehatan harus segera dilengkapi oleh petugas medis yang bersangkutan setelah pelayanan kepada pasien selesai .

Terisinya data yang lengkap pada formulir resume medis pasien salah satunya alasan dirawat, diagnosa masuk dan keluar sehingga informasi tentang riwayat penyakit pasien dapat berkesinambungan. Diagnosa masuk dan keluar juga sangat penting karena dapat mengetahui penyakit pasien dan untuk tindak lanjut pengobatan yang akan dilakukan.

\section{Temuan Fisik Penting dan Temuan- temuan Lain}

Berdasarkan hasil penelitian, untuk kelengkapan temuan fisik penting dan temuan-temuan lain sebesar $79 \%$ dan tidak lengkap sebesar 21\%. Bagian dari temuan fisik penting dan temuantemuan lain yaitu temuan kelainan fisik. Pengisian pada bagian ini banyak yang lengkap dikarenakan adanya temuan kelainan selain penyakitnya sehingga diisi agar tahu temuan lainnya dan dapat daijadikan sebagai tindak lanjut pengobatan berikutnya. Sedangkan untuk pengisian yang tidak lengkap dikarenakan ada pasien yang tidak memiliki kelainan fisik lain sehingga tidak diisi dan sebaiknya diisi dengan tanda - jika tidak ada kelainan fisik (Sudra, 2013).

Berdasarkan buku SNARS bahwa temuan fisik penting dan temuantemuan lain harus diisi dengan lengkap 
agar memenuhi standar yang diberikan. Menurut Permenkes Nomor 269/MenKes/Per/III/2008 tentang Rekam Medis bahwa petugas medis harus segera melengkapi rekam medis pasien setelah pelayanan kepada pasien selesai salah satunya pada formulir resume medis pasien yang memuat identitas pasien, diagnosa masuk dan indikasi pasien dirawat, ringkasan hasil pemeriksaan fisik dan penunjang, diagnosis akhir, pengobatan dan tindak lanjut, nama dan tanda tangan dokter atau dokter gigi yang memberikan pelayanan kesehatan.

Terisinya data yang lengkap pada temuan fisik penting dan temuantemuan lain maka informasi tentang temuan penyakit lain dapat diketahui oleh petugas medis sehingga dapat dijadikan acuan untuk dilakukan tindak lanjut pengobatan untuk penyakitnya.

\section{Tindakan Diagnostik dan Prosedur Terapi yang Telah Dikerjakan}

Berdasarkan hasil penelitian, untuk kelengkapan tindakan diagnostik dan prosedur terapi yang telah dikerjakan sebesar 54\% dan tidak lengkap sebesar $46 \%$. Bagian dari tindakan diagnostik dan prosedur terapi yang telah dikerjakan terdiri dari prosedur diagnostik yang dilakukan dan prosedur terapeutik/operasi yang diberikan. Pengisian pada bagian ini banyak yang lengkap karena terkait dengan tindakan yang diberikan kepada pasien yang dapat dijadikan acuan untuk pengobatan pengobatan selanjutnya. Sedangkan untuk pengisian yang tidak lengkap dikarenakan ada pasien yang tidak dilakukan tindakan hanya pemeriksaan sehingga tidak diisi dan sebaiknya diisi dengan tanda - jika tidak ada tindakan yang diberikan (Sudra, 2013).

Menurut UU RI No. 29 Tahun 2009 bahwa rekam medis harus diisi minimal identitas pasien, pemeriksaan, pengobatan, tindakan dan pelayanan lain yang telah diberikan kepada pasien dan harus segera dilengkapi oleh dokter atau dokter gigi setelah pelayanan kepada pasien selesai.
Terisinya data yang lengkap pada tindakan diagnostik dan prosedur terapi yang telah dikerjakan sehingga pada saat pengobatan selanjutnya dapat diketahui tindakan awal yang telah dilakukan maka isi dan tindakan yang diberikan dapat berkesinambungan.

\section{Obat yang Diberikan selama Dirawat Inap dengan Potensi Akibat Efek Residual Setelah Obat Tidak Diteruskan dan Semua Obat yang Harus Digunakan di Rumah}

Berdasarkan hasil penelitian, untuk kelengkapan obat yang diberikan selama dirawat inap dengan potensi akibat efek residual setelah obat tidak diteruskan dan semua obat yang harus digunakan di rumah sebesar $64 \%$ dan tidak lengkap sebesar 36\%. Bagian dari obat yang diberikan selama dirawat inap dengan potensi akibat efek residual setelah obat tidak diteruskan dan semua obat yang harus digunakan di rumah terdiri dari obat rawat inap dan obat yang dibawa pulang. Pengisian pada bagian ini banyak yang lengkap karena terkait dengan obat yang diberikan kepada pasien selama dirawat dan obat yang dibawa pulang. Sedangkan untuk pengisian yang tidak lengkap dikarenakan dokter lupa tidak mengisi untuk obat yang digunakan selama dirawat inap sehingga kosong hanya terisi obat yang dibawa pulang.

Menurut UU RI No. 29 Tahun 2009 bahwa rekam medis harus diisi oleh tenaga medis setelah pelayanan kepada pasien selesai dengan minimal pengisian identitas pasien, pemeriksaan, pengobatan, tindakan dan pelayanan lain yang telah diberikan kepada pasien.

Terisinya data yang lengkap pada obat yang diberikan selama dirawat inap dengan potensi akibat efek residual setelah obat tidak diteruskan dan semua obat yang harus digunakan di rumah sehingga untuk pengobatan selanjutnya dapat diketahui obat apa saja yang akan digunakan karena sudah tercantum obat yang terdahulu sehingga obat dan penyakit dapat berkesinambungan apakah obat tersebut dilanjutkan atau diganti dengan obat yang lain. 


\section{Jurnal Delima Harapan $\mathbf{2 0 2 0}$}

\section{Kondisi Pasien (Status Present)}

Berdasarkan hasil penelitian, untuk kelengkapan kondisi pasien (status present) sebesar $74 \%$ dan tidak lengkap sebesar $26 \%$. Bagian dari kondisi pasien (status present) terdiri dari $\mathrm{KU}$, kesadaran, tensi, nadi dan RR. Pengisian pada bagian ini banyak yang lengkap karena terkait dengan kondisi pasien yang harus dikontrol. Sedangkan untuk pengisian yang tidak lengkap dikarenakan dokter lupa kurang mengisi untuk bagian tensi dan RR nya atau kesadarannya dan ada yang tidak diisi sama sekali karena adanya miss komunikasi antara dokter dan perawat.

Menurut Depkes RI (2006) bahwa pasien perlu berobat jalan, mampu bergerak sendiri dan pasien mampu bekerja menunjukkan keadaan pasien saat keluar. Tujuan dari kondisi pasien harus diisi agar dapat dijadikan acuan untuk pengambilan keputusan di rumah sakit karena dengan diisi lengkap maka rumah sakit dapat melakukan evaluasi mutu pelayanan yang diberikan oleh tenaga medis dengan melihat hasil dari kondisi pasien tersebut.

Terisinya data yang lengkap pada kondisi pasien (status present) sehingga untuk rumah sakit dapat mengevaluasi bagaiamana mutu pelayanan yang telah diberikan. Jika tidak terisi maka rumah sakit tidak mengetahui kondisi pasien saat keluar rumah sakit sehingga mutu pelayanan yang diberikan kurang saat dilakukan pengambilan keputusan.

\section{Ringkasan Memuat Instruksi Tindak Lanjut}

Berdasarkan hasil penelitian, untuk kelengkapan ringkasan memuat instruksi tindak lanjut sebesar 37\% dan tidak lengkap sebesar 63\%. Bagian dari ringkasan memuat instruksi tindak lanjut terdiri dari kontrol, diet, latihan dan edukasi. Pengisian pada bagian ini banyak yang tidak lengkap karena dokter hanya mengisi bagian kontrol sedangkan untuk bagian diet, latihan dan edukasi tidak diisi jika tidak ada juga tidak diberi tanda -. Alasan tidak diisi karena bagian kontrol sudah diisi sehingga dokter tidak menuliskan diet, latihan dan edukasi karena untuk mempercepat pelayanan kepada pasien. Sedangkan untuk pengisian yang lengkap dikarenakan dokter rajin dan bertanggungjawab atas pelayanan yang diberikan kepada pasien karena terkait tindak lanjut pasien.

Menurut Permenkes Nomor 269/MenKes/Per/III/2008 tentang Rekam Medis bahwa petugas medis harus segera melengkapi rekam medis pasien setelah pelayanan kepada pasien selesai salah satunya pada formulir resume medis pasien yang memuat identitas pasien, diagnosa masuk dan indikasi pasien dirawat, ringkasan hasil pemeriksaan fisik dan penunjang, diagnosis akhir, pengobatan dan tindak lanjut, nama dan tanda tangan dokter atau dokter gigi yang memberikan pelayanan kesehatan.

Terisinya data yang lengkap pada ringkasan memuat instruksi tindak lanjut sehingga pasien dapat mengetahui apa saja yang harus dilakukan setelah pulang rawat inap seperti disarankan untuk kontrol ataupun diet. Jika diisi lengkap maka rumah sakit juga dapat melakukan evaluasi terhadap pelayanan yang diberikan.

\section{Ringkasan Pasien Pulang Dijelaskan dan Ditandatangani oleh Pasien/Keluarga.}

Berdasarkan hasil penelitian, untuk kelengkapan ringkasan pasien pulang dijelaskan dan ditandatangani oleh pasien/keluarga sebesar $76 \%$ dan tidak lengkap sebesar 24\%. Bagian dari ringkasan pasien pulang dijelaskan dan ditandatangani oleh pasien/keluarga terdiri dari tanda tangan dokter dan pasien/keluarga. Pengisian pada bagian ini banyak yang lengkap karena terkait dengan penanggung jawab pasien. Dokter yang bertanggungjawab terhadap perawatan pasien dan keluarga pasien yang menyetujui untuk perawatan. Kelengkapan tertinggi pada tanda tangan karena tanda tangan sangat penting saat ada permintaan dari pengadilan sebagai penanggung jawab. Sedangkan untuk pengisian yang tidak lengkap dikarenakan dokter, tenaga 


\section{Jurnal Delima Harapan $\mathbf{2 0 2 0}$}

medis dan keluarga pasien lupa untuk tanda tangan dan nama terang.

Menurut Hatta (2010), bukti tanda tangan dan nama terang yang merawat pasien dapat dijadikan informasi yang isinya dapat dipertanggungjawabkan secara hukum dengan menelaah tanda bukti keabsahan rekaman dari tenaga kesehatan atau tenaga lain yang terkait dalam pelayanan kepada pasien.

Terisinya data yang lengkap pada ringkasan pasien pulang dijelaskan dan ditandatangani oleh pasien/keluarga sehingga ketika ada pengajuan di jalur hukum maka ada bukti tanda tangan dan nama terang yang merawat pasien dan saksi dari keluarga pasien yang bertanda tangan.

\section{KESIMPULAN}

Isi resume medis secara kuantitatif terdiri dari nama, tanggal lahir/umur, ruang, tanggal masuk, tanggal keluar dan lama dirawat. Isi resume medis sesuai dengan SNARS terdiri dari indikasi pasien masuk dirawat, diagnosis dan komorbiditas lain, temuan fisik penting dan temuan-temuan lain, tindakan diagnostik dan prosedur terapi yang telah dikerjakan, obat yang diberikan selama dirawat inap dengan potensi akibat efek residual setelah obat tidak diteruskan dan semua obat yang harus digunakan di rumah, kondisi pasien (status present), ringkasan memuat instruksi tindak lanjut dan ringkasan pasien pulang dijelaskan dan ditandatangani oleh pasien/keluarga. Kelengkapan rata-rata keseluruhan resume medis sesuai dengan SNARS sebesar $60 \%$ dan tidak lengkap sebesar $40 \%$ dari 95 berkas rekam medis.

Saran yang dapat diberikan kepada RSUD dr. Soedono Madiun yaitu sebaiknya memberikan sosialisasi, pelatihan dan pendidikan kepada petugas medis tentang pengisian formulir resume medis dan kelengkapannya di RSUD dr. Soedono Madiun dan sebaiknya rumah sakit melakukan concurrent analysis yaitu analisis yang dilakukan pada saat pasien masih dirawat atau selama perawatan berlangsung yang dilakukan di ruang perawatan dengan tujuan untuk meminimalisir ketidaklengkapan pengisian rekam medis. Saran yang dapat diberikan kepada STIKES Buana Husada Ponorogo yaitu hasil dari penelitian ini dapat dijadikan sebagai bahan literatur bagi akademik dan sumber pengetahuan bagi mahasiswa. Saran yang dapat diberikan kepada peneliti yaitu hasil penelitian ini diharapkan dapat menambah ilmu pengetahuan dan pengalaman tentang rekam medis. Saran yang dapatdiberikan kepada peneliti lain yaitu hasil penelitian ini dapat dijadikan referensi untuk melakukan penelitian selanjutnya tentang rekam medis.

\section{DAFTAR PUSTAKA}

Anggraeni, D,M \& Saryono, 2013. Metodologi Penelitian Kuantitatif dan Kualitatif dalam Bidang Kesehatan. Yogyakarta : Nuha Medika.

Budi, Savitri Citra, 2011. Manajemen Unit Kerja Rekam Medis. Yogyakarta : Quantum Sinergis Media.

Depkes RI. 2006. Pedoman Penyelenggaraan dan Prosedur Rekam Medis Rumah Sakit di Indonesia. Jakarta : Depkes RI

Hatta, Gemala R, 2010. Pedoman Manajemen Informasi Kesehatan di Sarana Pelayanan Kesehatan. Jakarta : UI-PRESS.

Hatta, Gemala R. 2013. Pedoman Manajemen Informasi Kesehatan di Sarana Pelayanan Kesehatan. Edisi Revisi 2. Jakarta: UI-Press.

Notoatmodjo, S, 2010. Metodologi Penelitian Kesehatan. Jakarta : Rineka Cipta.

Permenkes RI No. 269/MENKES/PER/III/2008 tentang Rekam Medis

Permenkes RI No. 4 Tahun 2018 tentang Kewajiban Rumah Sakit dan Kewajiban Pasien

Sudra, Rano Indradi. 2013. Rekam Medis Edisi Kedua. Tangerang Selatan: Penerbit Universitas Terbuka. 
Sugiyono. 2016. Metode Penelitian

Kuantitatif, Kualitatif, dan $R \& D$.

Bandung: Alfabeta.

Sutoto, M.Kes, 2017. Standar Nasional Akreditasi Rumah Sakit Edisi 1. Jakarta : Komisi Akreditasi Rumah Sakit (KARS).

Undang-Undang RI No. 44 Tahun 2009 tentang Rumah Sakit

Undang-Undang Praktik Kedokteran Nomor 29 Tahun 2004

Undang - Undang RI No. 29 Tahun 2009 tentang Praktik Kedokteran 